\title{
Praktik Manajemen Laba dan Reaksi Pasar Setelah Event Pergantian Chief Executive Officer (CEO)
}

\author{
Desak Nyoman Sri Juliartini ${ }^{1}$ \\ Fakultas Ekonomi dan Bisnis \\ Universitas Udayana, Indonesia
}

\author{
Ida Bagus Putra Astika ${ }^{2}$ \\ Fakultas Ekonomi dan Bisnis \\ Universitas Udayana, Indonesia
}

\begin{abstract}
Surel : srijuliartini24@gmail.com
ABSTRAK

Penelitian ini untuk membuktikan setelah pergantian chief executive officer (CEO) adanya praktik manajemen laba dan reaksi pasar. Total sampel yang diambil menggunakan metode nonprabability sampling dengan teknik purposive sampling sebanyak 48 perusahaan di BEI yang termasuk indeks LQ45. Teknik analisis yang digunakan adalah regresi linier sederhana dan paired sample t-test pada nilai DA dan PER perusahaan. Berdasarkan hasil analisis ditemukan bahwa tidak terdapat pengaruh manajemen laba pada reaksi pasar setelah satu dan dua tahun pergantian CEO. Hasil ini membuktikan bahwa tidak terdapatinformasi yang penting pada pengumuman pergantian CEO, sehingga kurang mampu membuat fluktuasi harga saham yang signifikan. Hasil selanjutnya tidak terdapat perbedaan baik itu manajemen laba maupun reaksi pasar yang terjadi pada satu dan dua tahun setelah pergantian CEO.
\end{abstract}

Kata Kunci: Chief Executive Officer (CEO); Manajemen Laba; Reaksi Pasar; Price Earning Ratio (PER).

\section{Earning Management Practice and Market Reaction After Event Chief Executive Officer Turnover (CEO)}

\section{ABSTRACT}

This research is to prove after the change of chief executive officer (CEO) of earnings management practices and market reaction. The total sample taken was using the nonprabability sampling method with a purposive sampling technique of 48 companies on the IDX which included the LQ45 index. The analysis technique used is simple linear regression and paired sample t-test on the DA and PER values of the company. Based on the results of the analysis found that there is no effect of earnings management on market reaction after one and two years of CEO turnover. These results prove that there is no important information on the announcement of CEO turnover, so it is less able to make significant stock price fluctuations. The next result is no difference in both earnings management and market reaction that occurs one and two years after CEO turnover.

Keywords: $\quad$ Chief Executive Officer (CEO); Earning Management; Market Reaction; Price Earning Ratio (PER).

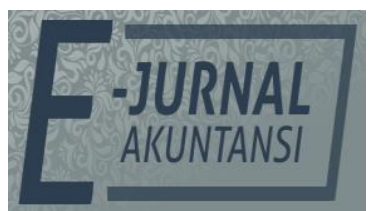

e-ISSN 2302-8556

Vol. 31 No. 4

Denpasar, April 2021

Hal. 795-808

DOI:

10.24843/EJA.2021.v31.i04.p01

PENGUTIPAN:

Juliartini, D.N.S., \& Astika, I.B.P. (2021). Praktik

Manajemen Laba dan Reaksi Pasar Setelah Event

Pergantian Chief Executive Officer (CEO). E-Jurnal Akuntansi, 31(4), 795-808

RIWAYAT ARTIKEL: Artikel Masuk: 7 Juni 2020 Artikel Diterima: 19 Februari 2021

Artikel dapat diakses : https://ojs.unud.ac.id/index.php/Akuntansi/index 


\section{PENDAHULUAN}

Manajemen laba adalah aktivitas memalsukan laporan keuangan menggunakan langkah-langkah akuntansi yang cocok untuk memperoleh jumlah laba yang diinginkan (Putri \& Fadhlia, 2017). Manajemen laba merupakan suatu fenomena yang sampai saat ini masih diperdebatkan mengenai pemahaman etis dan tanggung jawab sosialnya. Ada beberapa faktor yang mempengaruhi tindakan manajemen laba, salah satunya terjadi pergantian Chief Executive Officer yang seterusnya akan disebut CEO (Swasti et al., 2016). Hal tersebut diakibatkan dari CEO sebagai agenyang diberi wewenang pada proses rencana danpengambilan ketetapan perusahaan dalam memperoleh maksud khusus (Sadia \& Sukartha, 2014).

Pergantian CEO merupakan sinyal akan terjadi pergantian pada proses pelaksanaan dan pencapaian tujuan perusahaan dengan mengunakan aturan dan tahapan baru, serta pergantian konsep yang ditentukan oleh CEO pengganti (Novitasari et al., 2016). Kinerja perusahaan dapat diketahui dari output kinerja manajemen tertinggi pada pengelolaan usaha secara berlanjut agartercapai goal. Kinerja CEO terlihat baik bila mempunyai hasil kerja yang bagus setiap tahunnya serta mampu menggapai goal bersama.

Reaksi pasar akan timbul jika suatu pengumuman mengandung suatu informasi. Biasanya suatu pengumuman tersebut diberikan reaksi yang berlebihan oleh investor. Reaksinya berupa penetapan harga yang tinggi pada informasi yang dianggap bagus dan penetapan harga yang rendah terhadap informasi yang kurang bagus (Swasti et al., 2016). Perusahaan go public adalah perusahaan yang tercatat di BEI. Suatu indeks diperlukan sebagai sebuah indikator untuk mengamati pergerakan harga dari sekuritas-sekuritas (Jogiyanto, 2017). Fenomena yang terjadi akhir-akhir ini seperti kasus yang menimpa PT Garuda Indonesia Tbk (GIAA). Garuda tidak menyampaikan kondisi keuangan sesuai dengan kondisi sebenarnya yang menyebabkan para investor memberikan reaksi yang salah.

Hal yang diperoleh dari artikel terdahulu memperlihatkan manajemen laba dipengaruhi salah satunya perubahan CEO (Putri \& Ramantha, 2014), penghindaran pajak (Larastomo et al., 2016) dan kompensasi eskekutif (Hassen, 2014). Terdapat beberapa penelitian terkait dengan tindakan manajemen laba serta pergerakan saham dalam peristiwa perubahan CEO. Pada penelitian (Putri \& Ramantha, 2014) yang diproksikan menggunakan modified jones model menyebutkan tidak semua CEO melakukan manajemen laba yang menaikan laba. Penelitian dari (Sadia \& Sukartha, 2014) menyimpulkan kecenderunganpada perubahan CEO dilakukan aktivitas manajemen laba dari CEO pengganti mengikuti pola mengurangiincome. Menurut Adiasih dan Kusuma, (2011) dalam (Swasti et al., 2016) bahwa CEO melakukan praktik menurunkan laba sebelum dilakukan pergantian CEO serta melakukan praktik meningkatkan laba sesudah pergantian CEO. Untuk penelitian mengenai reaksi pasar, menurut penelitian (Swasti et al., 2016) terdapat perbedaan reaksi pasar pada pergantian CEO rutin maupun pergantian CEO non rutin. Sedangkan penelitian (Jayanthi \& Putra, 2013) menemukan hasil saat permulaan pemegang perusaahan CEO pengganti diketahui adanya aktivitas mengurangi income namun direspon positif oleh pasar, begitu pula pada periode akhir jabatan CEO 
lama adanya praktik menaikkan laba namun direspon negatif oleh investor.Penelitian ini kembali menguji hubungan peristiwa pergantian CEO terhadap manajemen laba dan reaksi pasar. Hasil penelitian tentang aktivitas manajemen laba serta pergerakan saham saat peristiwa perubahan CEO masih terdapat inkonsistensi serta adanya kasus yang menimpa salah satu perusahaan go public akhir-akhir ini mendorong penelitian ini masih layak untuk dilakukan.

Teori keagenan adalah pendesainan kontrak yang tepat untuk menyelaraskan kepentingan prinsipal dan agen dalam hal terjadi konflik kepentingan (Scott, 2015). Teori keagenan dalam penelitian ini menjelaskan tentang konflik CEO sebagai agen dalam perusahaan dengan pemegang saham sebagai prinsipal. Pergantian CEO biasanya dipicu oleh tidak tercapainya tujuan kedua pihak yaitu antara manajer dengan pemilik perusahaan. Brigham dan Houston (2008) mendefinisikan sinyal atau isyarat adalah suatu tindakan yang diambil perusahaan untuk memberi petunjuk bagi invetor tentang bagaimana manajemen memandang propek perusahaan. Sinyal adalah tindakan yang digunakan perusahaan untuk memberikan petunjuk para investor tentang pandangan manajemen mengenai propek perusahaan. Sinyal yang dikeluarkan perusahaan merupakan suatu informasi yang hakekatnya menyajikan keterangan, catatan atau gambaran, baik untuk keadaan masa lalu, kinerja perusahaan saat ini maupun untuk memprediksi kondisi perusahaan di masa yang akan datang bagi kelangsungan hidup perusahaan. CEO merupakan eksekutif yang berada dipuncak perusahaan dan yang bertanggung jawab untuk kelangsungan hidup dan keberhasilan perusahaan. CEO di Indonesia biasanya disebut direktur atau dewan direksi. Menurut Bengtsson et al, (2006) pergantian CEO adalah suatu peristiwa ketika CEO dari suatu organisasi digantikan oleh individu lain. Menurut Clayton et al, (2003) hasil keputusan yang berbeda dari tiap anggota RUPS dalam pergantian CEO dapat mengubah jalan perusahaan dan kenerja perusahaan. CEO dalam perusahaan memiliki peran yang penting dalam pengelolaan perusahaan. Kinerja perusahaan yang buruk selalu dihubungkan dengan terjadinya pergantian CEO.Manajemen laba adalah pemilihan kebijakan akuntansi tertentu oleh manajer untuk mencapai tujuan tertentu (Scott, 2015). Manajemen laba ini tidak mempengaruhi profitabilitas perusahaan dalam jangka panjang. Manajemen laba yang dilakukan manajemen tidak melanggar standar akuntansi tertentu dalam batasan prinsip akuntansi. Reaksi pasar akan timbul jika suatu pengumuman mengandung suatu informasi. Reaksi pasar ditunjukkan dari adanya perubahan harga saham dan volume perdagangan saham. Reaksi pasar dapat diukur menggunakan abnormal return dan pendekatan PER. Dalam penelitian ini akan digunakan pendekatan PER atau disebut juga pendekatan earning multiplier. Rasio ini menunjukkan berapa besar investor menilai harga saham terhadap kelipatan earnings(Jogiyanto, 2017). Hukum besi merupakan hukum yang berlaku dalam akuntansi keuangan. Hukum ini dikenal karena berada di sekitar manajemen laba dalam bentuk "accruals reserve"(Astika, 2009). Hukum ini menjelaskan secara implisit bahwa manajer akan mengembalikan keadaan ke semula dengan mambuat jurnal balik setelah dua tahun pengumuman pergantian CEO. 


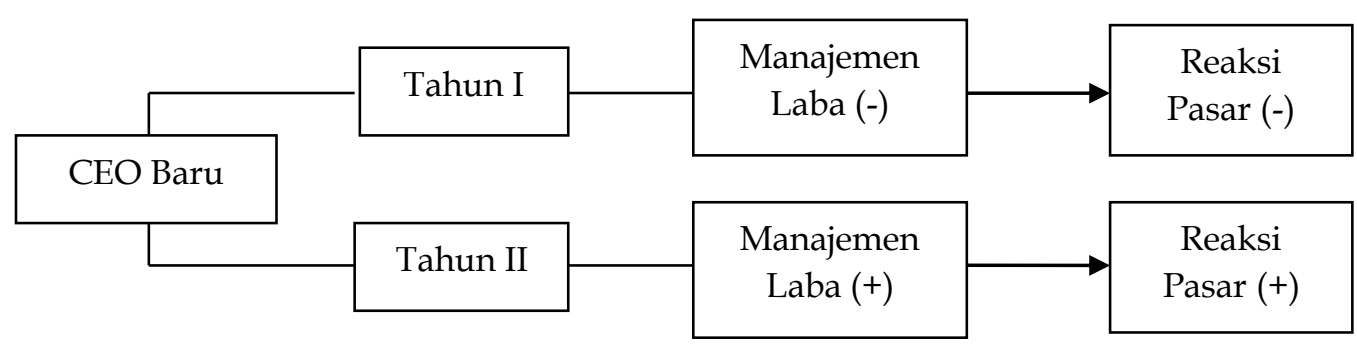

Sumber: Data Penelitian, 2020

Gambar 1. Kerangka Konseptual

Perubahan CEO mendorong CEO pengganti agar melaksanakan aktivitas manajemen income memakai cara mengurangi pendapatan atau beban(income decreasing) yang ditunjukkan dariangka rata-rata discretionaryaccruals yang minus (Wijaya and Ardiana, 2014). Hasil penelitian tersebut mengungkapkan ketika perubahan CEO tindakan manajemen laba cenderung mengurangi laba. Oleh karena itu hipotesis yang diajukan dalam penelitian ini yaitu sebagai berikut.

$\mathrm{H}_{1}$ : Manajemen melakukan manajemen laba dengan pola income decreasing setelah satu tahun pergantian CEO.

Laporan yang dikeluarkan perusahaan dapat dimanfaatkan sebagai acuan bagi investor mengambil tindakan di pasar modal. Semua hal yang disebar luaskan oleh perusahaan diharapkan akan memberikan pertimbangan bagi investor apabila memilki kandungan informasi. Menurut Mahoni (2015) bahwa pasar atau para investor tidak merespon informasi pergantian CEO rutin yang dilihat dari nilai rata-rata yang negatif dan menurun. Oleh karena itu hipotesis kedua yang ditetapkan adalah sebagai berikut.

$\mathrm{H}_{2}$ : Manajemen laba dengan pola income decreasing berpengaruh negatif pada reaksi pasar setelah satu tahun pergantian CEO.

Manajemen laba yang sering dilakukan manajer biasanya terjadi sekitar event pergantian CEO salah satunya setelah dilakukannya pergantian CEO. Manajemen laba ini dilakukan untuk mempertahankan kedudukannya sebagai CEO pada periode berikutnya atau mendapatkan bayaran lebih besar di akhir pekerjaannya. CEO baru pada tahun kedua biasanya melakukan income increasing alasannya CEO baru membuktikan kinerjanya yang lebih baik dari CEO lama kepada perusahaan serta memperoleh bonus untuk pencapaian laba pada tahun tersebut. Oleh karena itu hipotesis yang diajukan adalah sebagai berikut.

$\mathrm{H}_{3}$ : Terjadi manajemen laba dengan pola income increasing pada dua tahun setelah pergantian CEO.

Teori sinyal menyatakan bahwa suatu pengumuman dianggap positif jika manajer perusahaan menyampaikan perspektif masa depan perusahaan yang baik ke publik. Sinyal dianggap valid dan dapat dipercaya oleh pasar, apabila perusahaan benar-benar mempunyai kondisi sesuai yang disinyalkan yang mendapatkan reaksi positif. Pengumuman pergantian CEO non rutin memberikan dampak posistif terhadap reaksi pasar karena sangat terkait dengan gaya kepemimpinan baru yang berbeda dari CEO sebelumnya. Pengumuman ini dianggap informasi yang berguna untuk menentukan keputusan dalam berinvestasi. Menurut Setiawan et al., (2011) menyatakan bahwa pergantian CEO rutin memberikan dampak positif terhadap reaksi pasar. Oleh karena itu hipotesis yang diajukan adalah sebagai berikut. 
$\mathrm{H}_{4}$ : Manajemen laba dengan pola income increasing berpengaruh positif pada reaksi pasar setelah dua tahun pergantian CEO.

Reaksi pasar tercermin dari nilai Price Earning Ratio (PER) dengan perhitungan harga saham dan keuntungan tahunan perusahaan. Perubahan CEO adalah salah satu kegiatan dalam perusahaan baik secara terutin ataupun tidak terutin. Warner et al., (1988) menyampaikan bahwa aktivitas perubahan manajemen utama pada pergerakan pasar yang dilihat dari harga saham sangat sedikit. Sedangkan menurut Setiawan et al., (2011) adanya informasi orang yang menggantikan CEO secara non-rutin merupakan isyarat gabungan bagi investor. Para investor kurang percaya mengenai manajemen yang akan dilakukan CEO pengganti di perusahaan. Pernyataan tersebut diketahui dari reaksi yang tidak sama dalam satu periode pergantian. Oleh karena itu hipotesis yang diajukan adalah sebagai berikut.

$\mathrm{H}_{5}$ : Terdapat perbedaan reaksi pasar antara satu dan dua tahun setelah pergantian CEO.

Menurut hasil dari penelitian Dhinata \& Wirama (2015) terdapat perusahaan yang melakukan pergantian CEO menunjukkan pola merendahkan laba (income decreasing). Pernyataan tersebut mengandung maksudtidak semua CEO pengganti mengadakan manajemen laba dengan menaikkan laba (income increasing) pada kurun waktu permulaan pekerjaannya.Wells (2002), menjelaskan CEO yang baru menjabat memiliki kesempatan lebih besar untuk memberikan atribut buruk pada pendahulunya yang tidak tinggal lagi di perusahaan dengan mengadakan manajemen laba yang merendahkan laba, bukanlah satu-satunya pemicu praktik manajemen laba yang diadakan CEO pengganti saat kurun waktu permulaan pekerjaannya. Dengan tidak dipisahkannya jenis perubahan CEO pada artikel ini, praktik manajemen laba ternyata tetap terbukti secara statistik dilakukan oleh CEO baru pada perusahaan-perusahaan yang terdaftar di Bursa Efek Indonesia. Oleh karena itu hipotesis yang diajukan adalah sebagai berikut.

$\mathrm{H}_{6}$ : Terdapat perbedaan manajemen laba antara satu dan dua tahun setelah pergantian CEO

\section{METODE PENELITIAN}

Penelitian ini memakai data sekunder perusahaan go-public yang tercatat dalam indeks LQ45 tahun 2008-2018 diperoleh dengan mengakses website Bursa Efek Indonesia yaitu www.idx.co.id, www.finace.com, www.sahamok.com, dan Indonesian Capital Market Directory (ICMD). Obyek pada artikel ini adalah pergerakan pasar yang terjadi pada perusahaan go-public yang tercatat dalam indeks LQ45 dan mengalami pergantian CEO pada periode 2008-2018. Variabel bebas dalam artikel ini adalah manajemen laba (X). Variabel terikat dalam penelitian ini adalah reaksi pasar (Y). Manajemen laba dalam penelitian ini diproksikan dengan Discretionary Accruals (DA) yang diperoleh melalui modified Jones model yang dikembangkan oleh Dechow, et al. (1995). Modified Jones model menghitung manajemen laba dengan langkah-langkah sebagai berikut: 1) Menghitung total akrual (Dechow, et al. 1995) $\left(\mathrm{TAC}_{\mathrm{it}}=\mathrm{NI}_{\mathrm{it}}-\mathrm{CFO}_{\mathrm{it}}\right), 2$ ) Menghitung koefisien regresi dengan Ordinary Least Square (Dechow, et al. 1995) $\left(\mathrm{TAC}_{\mathrm{it}} / \mathrm{A}_{\mathrm{it}-1}=\beta_{1}\left(1 / \mathrm{A}_{\mathrm{it}-1}\right)+\beta_{2}\left(\mathrm{REV}_{\mathrm{it}} / \mathrm{A}_{\mathrm{it}-1}\right)+\beta_{3}\left(\mathrm{PPE}_{\mathrm{it}} / \mathrm{A}_{\mathrm{it}-1}\right)+\varepsilon\right)$, 3) Menghitung 
Non Discretionary Accruals (NDA) (Dechow, et al. 1995) $\left(\mathrm{NDA}_{\mathrm{it}}=\beta_{1}\left(1 / \mathrm{A}_{\mathrm{it}}\right.\right.$ $\left.\left.\left.{ }_{1}\right)+\beta_{2}\left(\left(\Delta \mathrm{REV}_{\mathrm{it}}-\Delta \mathrm{REC}_{\mathrm{it}}\right) / \mathrm{A}_{\mathrm{it}-1}\right)\right)+\beta_{3}\left(\mathrm{PPE}_{\mathrm{it}} / \mathrm{A}_{\mathrm{it}-1}\right)\right)$, 4) Menghitung Discretionary Accruals (DA) (Dechow, et al. 1995) $\left(\mathrm{DA}_{\mathrm{it}}=\left(\mathrm{TA}_{\mathrm{it}} / \mathrm{A}_{\mathrm{it}-1}\right)-\mathrm{NDA}_{\mathrm{it}}\right)$.

Dalam penelitian ini digunakan salah satu rasio kinerja yaitu price earning ratio (PER). Rasio ini menunjukkan berapa besar investor menilai harga dari saham terhadap kelipatan dari earning (Jogiyanto,2017 224-225).Menghitung price earning ratio (Jogiyanto,2017 224-225): $\mathrm{PER}_{\mathrm{it}}=\mathrm{P}_{\mathrm{it}} / \mathrm{E}_{\mathrm{it}}$.

Teknik pengambilan sampel dalam penelitian ini adalah purpose sampling. Pertimbangan-pertimbangan tersebut adalah sebagai berikut: 1) Emiten yang tercatat pada indeks LQ45 di Bursa Efek Indonesia selama tahun 2008-2018, 2) Emitengo public tiada mengalami delisting selama tahun 2008-2018, 3) Perusahaan menerbitkan laporan keuangan dan laporan tahunan lengkap untuk tahun 20082018 , 4) Perusahaan go public indeks LQ45yang terdaftar mengalami pergantian CEO baik itu rutin maupun non rutin pada tahun 2008-2018, 5) Perusahaan go public indeks LQ45 yang memakai standar rupiah (Rp) dalam laporan keuangan..

Metode pengumpulan data yang digunakan dalam penelitian ini adalah observasi non partisipan. Jenis data yang digunakan dalam penelitian ini adalah data kuantitatif dan kualitatif. Teknik analisis data yang digunakan untuk memecahkan permasalahan dalam penelitian ini adalah regresi linier sederhana dan uji paired sample t-test.

\section{HASIL DAN PEMBAHASAN}

Data penelitian ini merupakan emiten di BEI yang memberikan informasi ke publik mengenai perubahan CEO yang tergolong indeks LQ45 selama tahun 2008 hingga 2018. Selama 10 tahun tersebut terdapat 48 perusahaan yang layak digunakan sebagai sampel penelitian. Berikut Tabel 1, yang memperlihatkan secara rinci proses seleksi sampel penelitian.

Terdapat total 90 perusahaan yang terdaftar di indeks LQ45 dari Februari 2008 hingga Februari 2019. Perusahaan yang tidak menerbitkan laporan keuangan dan laporan tahunan lengkap dengan data yang diperlukan untuk tahun 2008-2018 berjumlah tiga perusahaan yaitu PT Waskita Karya Tbk, PT Gudang Garam Tbk dan PT Energi Mega Persada Tbk. Terdapat satu perusahaan yang mengalami delisting selama tahun 2008-2018 yaitu PT Berau Coal Energy Tbk. Terdapat 27 emiten yang tidak melakukan perubahan CEO karena faktor keberlanjutan masa jabatan CEO lama maupun periode pergantian CEO diluar periode pengamatan. Selanjutnya, terdapat sebelas perusahaan yang mengeluarkan laporan keuangan dengan menggunakan satuan selain Rupiah. Sehingga, hanya terdapat 48 perusahaan yang memenuhi kriteria untuk dianalisis. Berikut uji statistik deskriptif pada Tabel 1.

Tabel 1. Hasil Uji Statistik Deskriptif

\begin{tabular}{lccccc}
\hline \multicolumn{1}{c}{ Variabel } & N & Minimum & Maksimum & Rata-Rata & Standar Deviasi \\
\hline DA Setelah Satu Tahun & 48 & $-0,21$ & 0,28 & $-0,0020$ & 0,10310 \\
DA Setelah Dua Tahun & 48 & $-0,19$ & 0,19 & 0,0002 & 0,07743 \\
PER Setelah Satu Tahun & 48 & $-12,63$ & 48,24 & 14,3897 & 13,22141 \\
PER Setelah Dua Tahun & 48 & $-32,33$ & 46,74 & 14,9490 & 13,74830 \\
\hline
\end{tabular}

Sumber: Data Penelitian, 2020 
Hasil statistik deskriptif Manajemen laba yang diproksikan dengan DA setelah satu tahun pergantian CEO memiliki nilai minimum sebesar $-0,21$, nilai maksimum sebesar 0,28 , dan nilai rata-rata sebesar $-0,0020$, artinya bahwa nilai rata-ratanya memiliki kecondongan kearah nilai minimum serta nilai standar deviasi sebesar 0,09319. DA setelah dua tahun pergantian CEO memiliki nilai minimum sebesar $-0,19$, nilai maksimum sebesar 0,19 , dan nilai rata-rata sebesar 0,0002, artinya bahwa nilai rata-ratanya memiliki kecondongan kearah nilai maksimum serta nilai standar deviasi sebesar 0,07743. Reaksi pasar yang diproksikan dengan PER setelah satu tahun pergantian CEO memiliki nilai minimum sebesar -12,63, nilai maksimum sebesar 48,24, dan nilai rata-rata sebesar 14,3897, artinya bahwa nilai rata-ratanya memiliki kecondongan kearah nilai maksimum serta nilai standar deviasi sebesar 13,22141. PER setelah dua tahun pergantian CEO memiliki nilai minimum sebesar -32,33, nilai maksimum sebesar 46,74, dan nilai rata-rata sebesar 14,949, artinya bahwa nilai rata-ratanya memiliki kecondongan kearah nilai maksimum serta nilai standar deviasi sebesar 13,7483. Hasil pengujian kolmogorov-smirnov dapat dilihat pada Tabel 2.

\section{Tabel 2. Hasil Uji Normalitas}

\begin{tabular}{cccc}
\hline & N & Asymp. Sig. (2-tailed) & Keterangan \\
\hline Setelah Satu Tahun Pergantian CEO & 48 & 0,267 & Distribusi Normal \\
Setelah Dua Tahun Pergantian CEO & 48 & 0,604 & Distribusi Normal \\
\hline
\end{tabular}

Sumber: Data Penelitian, 2020

Berdasarkan Tabel 2, menunjukkan nilai Asymp.Sig. (2-tailed) untuk kelompok data tahun pertama setelah pergantian CEO sebesar 0,267. Hasil tersebut berada di atas tingkat signifikansi yang telah ditentukan yaitu 0,05. Asymp.Sig. (2-tailed) untuk kelompok data tahun kedua setelah pergantian CEO sebesar 0,604. Hasil tersebut berada di atas tingkat signifikansi yang telah ditentukan yaitu 0,05. Maka berdasarkan Kolmogorov-Smirnov test, kedua kelompok data berdistribusi normal. Hasil pengujian heteroskedastisitas dapat dilihat pada Tabel 3 .

\section{Tabel 3. Hasil Uji Heteroskedastisitas}

\begin{tabular}{cccc}
\hline Persamaan & Variabel Independen & Sig. & Keterangan \\
\hline \multirow{2}{*}{$\mathrm{Y}=\mathrm{a}+\beta \mathrm{X}$} & Manajemen Laba Tahun 1 & 0,405 & Bebas heteros \\
& Manajemen Laba Tahun 2 & 0,096 & Bebas heteros \\
\hline
\end{tabular}

Sumber: Data Penelitian, 2020

Berdasarkan Tabel 3, dapat dilihat bahwa nilai signifikansi dari variabel manajemen laba saat tahun pertama dan kedua setelah pergantian CEO masingmasing sebesar 0,405 dan 0,096. Nilai tersebut lebih besar dari 0,05 yang berarti tidak terdapat pengaruh antara variabel independen terhadap absolute residual. Dapat disimpulkan model yang dibuat tidak mengandung gejala heteroskedastisitas.Hasil pengujian autokorelasi dapat dilihat pada Tabel 4 .

Tabel 4. Hasil Uji Autokorelasi

\begin{tabular}{cccccc}
\hline Persamaan & Pengamatan & DL & DU & DW & Simpulan \\
\hline \multirow{2}{*}{$\mathrm{Y}=\mathrm{a}+\beta \mathrm{X}$} & Satu Tahun & 1,4928 & 1,5776 & 2,117 & Bebas autokorelasi \\
& Dua Tahun & 1,4928 & 1,5776 & 2,112 & Bebas autokorelasi \\
\hline
\end{tabular}

Sumber: Data Penelitian, 2020 
Berdasarkan Tabel 4, dapat dilihat pada persamaan regresi untuk tahun pertama memiliki nilai Durbin-Watson sebesar 2,117. Untuk tingkat signifikansi 0,05 , nilai $\mathrm{dl}=1,4928$ dan $\mathrm{du}=1,5776$. Hasil uji autokorelasi persamaan regresi untuk tahun pertama dengan kriteria du $<$ DW $<4$-du adalah $1,4928<2,117<2,4224$. Persamaan regresi tahun kedua memilki Durbin-Watson sebesar 2,112 untuk tingkat signifikansi 0,05 , nilai $d l=1,4928$ dan $d u=1,5776$. Hasil uji autokorelasi persamaan regresi tahun kedua dengan kriteria $\mathrm{du}<\mathrm{DW}<4$-du adalah $1,4928<2,112<2,4224$. Kesimpulan untuk kedua regresi ini tidak mengandung gejala autokorelasi.Hasil pengujian regresi linier sederhana dapat dilihat pada Tabel 5.

Tabel 5. Hasil Uji Regresi Linier Sederhana

\begin{tabular}{lcccc}
\hline \multicolumn{1}{c}{ Variabel } & Unstandardized & Std. Error & t hitung & Sig. uji t \\
\hline (Constant) & 14,426 & 1,91 & 7,553 & 0,000 \\
Manajemen Laba Tahun 1 & 18,107 & 18,718 & 0,967 & 0,338 \\
R Square & 0,020 & & & \\
(Constant) & 14,944 & 1,985 & 7,528 & 0,000 \\
Manajemen laba tahun 2 & 25,455 & 25,909 & 0,982 & 0,331 \\
$R$ Square & 0,021 & & & \\
\hline
\end{tabular}

Sumber: Data Penelitian, 2020

Berdasarakn Tabel 6, $R$ Square sebesar 0,020, yang mempunyai arti bahwa variasi reaksi pasar saat tahun setelah pergantian CEO hanya dipengaruhi $2 \%$ oleh manajemen laba atau bisa dikatakan bahwa tidak dipengaruhi oleh manajemen laba saat satu tahun setelah pergantian CEO. Nilai $R$ Square sebesar 0,021 , yang mempunyai arti bahwa sebesar $2,1 \%$ variasi reaksi pasar saat tahun kedua setelah pergantian CEO dipengaruhi oleh variansi manajemen laba atau bisa dikatakan bahwa reaksi pasar tidak dipengaruhi oleh variansi manajemen laba pada tahun kedua setelah pergantian CEO. Berdasarkan hasil analisis pengaruh manajemen laba pada reaksi pasar saat satu tahun setelah pergantian CEO diperoleh nilai signifikansi sebesar 0,338 dengan nilai koefisien beta 18,107. Nilai signifikansi 0,338>0,05 mengkan bahwa $\mathrm{H}_{0}$ diterima dan $\mathrm{H}_{1}$ ditolak. Hasil ini berarti manajemen laba dengan pola income decreasing saat satu tahun pertama setelah pergantian CEO tidak berpengaruh pada reaksi pasar. Berdasarakan hasil analisis pengaruh manajemen laba pada reaksi pasar saat tahun kedua setelah pergantian CEO diperoleh nilai signifikansi sebesar 0,304 dengan nilai koefisien beta 26,926. Nilai signifikansi 0,331>0,05 mengkan bahwa $\mathrm{H}_{0}$ diterima dan $\mathrm{H}_{1}$ ditolak. Hasil ini berarti manajemen laba dengan pola income increasing saat tahun kedua setelah pergantian CEO tidak berpengaruh pada reaksi pasar. Hasil uji paired sample t-test dapat dilihat pada Tabel 6.

Tabel 6. Hasil Uji Paired Sample T-test

\begin{tabular}{llcc}
\hline \multicolumn{1}{c}{ Variabel } & $\mathrm{N}$ & $\mathrm{t}$ & Sig. (2-tailed) \\
\hline Manajemen laba & 48 & 0,146 & 0,885 \\
Reaksi Pasar & 48 & 0,236 & 0,814 \\
\hline
\end{tabular}

Sumber: Data Penelitian, 2020

Berdasarkan Tabel 6, untuk variabel manajemen laba, nilai t sebesar 0,146 dengan asymp. Sig (2-tailed) 0,885 lebih besar dari 0,05. Nilai tersebut menyatakan bahwa tidak terdapat perbedaan manajemen laba antara setelah satu dan dua tahun pergantian CEO. Variabel reaksi pasar dalam uji paired sampel t-test 
memiliki nilai t sebesar 0,236 dengan asymp. Sig (2-tailed) 0,814 lebih besar dari 0,05 . Nilai tersebut menyatakan bahwa tidak terdapat perbedaan reaksi pasar antara setelah satu dan dua tahun pergantian CEO.

Berdasarkan hasil analisis adanya manajemen laba pada satu tahun pergantian CEO diperoleh nilai -0,0020 yang berarti bahwa rata-rata CEO baru pada perusahaan indeks LQ45 melakukan income decreasing saat satu tahun pertama setelah pergantian CEO. Perusahaan-perusahaan yang melakukan manajemen laba dengan pola income decreasing pada tahun pertama setelah pergantian CEO diantaranya tiga terendah, yaitu PT Visi Media Asia Tbk dengan nilai DA -0,21, lalu PT Indosat Tbk dengan nilai DA -0,168, lalu berikutnya adalah PT Bakrie Sumatera Plantations Tbk dengan nilai DA -0,15. Hasil penelitian ini sesuai dengan penelitian yang dilakukan oleh (Adiasih \& Kusuma2011), Choi et al., (2014), Yasa \& Novialy(2008), Erawan \& Ulupui(2013), Jayanthi \& Putra (2013), Wijaya \& Ardiana (2014), Sadia \& Sukartha (2014), Dhinata \& Wirama (2015) serta Noor \& Astika (2016)yang membuktikan bahwa terjadi praktik earnings management dengan income decreasing pada awal masa jabatan CEO baru. Berdasarkan hasil analisis adanya manajemen laba pada dua tahun pergantian CEO diperoleh nilai 0,0002 yang berarti bahwa rata-rata CEO baru pada perusahaan indeks LQ45 melakukan income increasing saat dua tahun setelah pergantian CEO. Perusahaan-perusahaan yang melakukan manajemen laba dengan pola income increasing pada tahun kedua setelah pergantian CEO diantaranya tiga tertinggi, yaitu PT Indomobil Sukses Internasional Tbk dengan nilai DA 0,193, lalu PT Bank Jawa Barat \& Banten Tbk dengan nilai DA 0,181, lalu berikutnya adalah PT Timah Tbk dengan nilai DA 0,149. Berdasarkan hasil tersebut sangat penting diketahui oleh investor dalam menentukan pilihan untuk melakukan investasi. Sesuai dengan teori yang dikembangkan oleh Astika (2009) hukum besi merupakan hukum yang berlaku dalam akuntansi keuangan. Hukum ini dikenal karena berada di sekitar manajemen laba dalam bentuk "accruals reserve". Hukum ini menjelaskan secara implisit bahwa manajer akan mengembalikan keadaan ke semula dengan mambuat jurnal balik setelah dua tahun pengumuman pergantian CEO. Hasil penelitian ini sesuai dengan penelitian yang dilakukan oleh Wijaya \& Ardiana (2014), Adhyatma \& Harto (2014), Yasa \& Novialy (2008), Bengtsson et al. (2006), Jin et al. (2010), Feng Yu (2012) dan Wells (2002) yang membuktikan bahwa terjadi praktik earnings management setelah pengumuman pergantian CEO.

Berdasarkan hasil analisis pengaruh manajemen laba pada reaksi pasar saat tahun pertama setelah pergantian CEO diperoleh nilai Signifikan sebesar 0,338 dengan nilai koefisien beta 18,107. Nilai Signifikansi 0,338 >0,05 mengkan bahwa $\mathrm{H}_{0}$ diterima dan $\mathrm{H}_{1}$ ditolak. Hasil ini berarti manajemen laba dengan pola income decreasing saat tahun pertama setelah pergantian CEO tidak berpengaruh pada reaksi pasar. Hasil penelitian ini sejalan dengan hasil penelitian sebelumnya dari Warner et al., (1988)menyimpulkan peristiwa pergantian manajemen puncak terhadap reaksi pasar yang dilihat dari harga saham sangat kecil. Penelitian Warner dilakukan dengan sampel 269 perusahaan yang listing di NYSE dan AMEX pada periode 1963-1978. Penelitian ini menunjukkan tidak ada reaksi pasar saat pengumuman tersebut. Penelitian ini juga sejalan dengan yang didapatkan oleh Raina (2018), Indah (2017) dan Nugraha (2014). Besar kecilnya 
manajemen laba yang dilakukan pihak manajemen perusahaan tidak berpengaruh signifikan terhadap reaksi pasar. Kondisi pasar modal Indonesia masih inefisiensi dimana dalam mengambil keputusan berinvestasi di pasar modal para investor (penanam modal) juga melihat dan mempertimbangkan kondisi di luar perusahaan dan isu yang beredar. Hasil penelitian ini tidak konsisten dengan penelitian yang dilakukan oleh Ardiati (2005) bahwa manajemen laba berpengaruh positif terhadap reaksi pasar yang diproksikan dengan return. Bertentangan juga dengan penelitian dari Gill, et al,. (2013), Ferro et al., (2014) dan Febriani (2014) yang menjelaskan bahwa manajemen laba pada tahun pertama setelah pergantian CEO berpengaruh negatif pada reaksi pasar.

Berdasarkan hasil analisis pengaruh manajemen laba pada reaksi pasar saat tahun kedua setelah pergantian CEO diperoleh nilai Signifikan sebesar 0,331 dengan nilai koefisien beta 25,455. Nilai Signifikansi 0,331>0,05 mengkan bahwa $\mathrm{H}_{0}$ diterima dan $\mathrm{H}_{1}$ ditolak. Hasil ini berarti manajemen laba dengan pola income increasing saat tahun kedua setelah pergantian CEO tidak berpengaruh pada reaksi pasar. Pasar tidak bereaksi terhadap perusahaan setelah dua tahun pergantian CEO. Penelitian ini memperoleh hasil bahwa setelah dua tahun pergantian CEO pasar menganggap bahwa tidak ada kandungan informasi dan tidak dapat mempengaruhi keputusan para investor dalam berinvestasi. Pergantian CEO merupakan salah satu fenomena internal perusahaan yang dilakukan secara rutin dan tidak rutin. Pergantian CEO adalah sinyal dari perusahaan bahwa mereka akan membuat perubahan dalam manajemen perusahaan (Setiawan et al., 2011). Setiawan et al. (2011) menyatakan perubahan CEO non-rutin adalah sinyal campuran untuk investor. Mereka tidak yakin tentang cara CEO baru mengelola perusahaan. Hal ini tercermin dengan hasil yang beragam pada periode tersebut, baik untuk perubahan non-rutin maupun di luar non-rutin. Hasil penelitian menunjukkan pada pergantian non-rutin, pasar tidak bereaksi terhadap informasi pergantian CEO. Hasil penelitian ini sejalan dengan hasil yang didapatkan oleh Raina (2018), Indah (2017) dan Nugraha (2014).

Hal tersebut mengkan bahwa tidak ada kandungan informasi pada dua tahun setelah pengumuman pergantian CEO sehingga tidak ada reaksi pasar. Pengumuman pergantian CEO tidak dapat menciptakan pergerakan pasar modal lebih berfluktuatif. Sehingga diidentifikasikan bahwa pengumuman pergantian CEO belum dapat menciptakan kenaikan harga saham yang signifikan. Maka investor tidak dianjurkan membeli saham setelah tanggal pergantian CEO. Hasil penelitian ini tidak konsisten dengan penelitian yang dilakukan oleh Susanto \& Christiawan (2016), Ridwan \& Gunardi (2013) serta Suffian, et al., (2015) yang menjelaskan bahwa manajemen laba dengan pola income increasing saat tahun kedua setelah pergantian CEO berpengaruh positif dan signifikan pada reaksi pasar.

Menurut Subramanyam (2013) bahwa manajer memilih akrual memungkinkan manajer mengkomunikasikan informasi privat mereka. Manajer juga memungkinkan mengunakan akrual untuk meningkatkan kemampuan laba untuk mencerminkan nilai ekonomis perusahaan. Laba akrual dipandang sebagai ukuran kinerja perusahaan yang lebih superior dibandingkan aliran kas 
karena akrual mengurangi masalah waktu dan ketidakcocokan yang melekat dalam pengukuran aliran kas.

Hipotesis kelima $\left(\mathrm{H}_{5}\right)$ menyatakan bahwa terdapat perbedaan reaksi pasar antara perusahaan LQ45 setelah satu dan dua tahun pengumuman pergantian CEO ditolak. Hasil ini membuktikan bahwa tidak terdapat perbedaan reaksi pasar antara satu dan dua tahun setelah pergantian CEO. Penelitian ini sejalan dengan hasil penelitian dari Warner et al., (1988) dan Agusnawan (2018) menyimpulkan peristiwa pergantian manajemen puncak terhadap reaksi pasar yang dilihat dari harga pasar sangat kecil. Penelitian ini menunjukkan tidak terdapat reaksi pasar saat pengumuman tersebut karena investor menganggap bahwa informasi yang dipublikasikan tidak mengandung informasi yang dapat digunakan sebagai pertimbangan dalam berinvestasi.

Hipotesis keenam $\left(\mathrm{H}_{6}\right)$ menyatakan bahwa terdapat perbedaan manajemen laba antara satu dan dua tahun setelah pergantian CEO ditolak. Hasil ini membuktikan bahwa tidak terdapat perbedaan manajemen laba atas pergantian CEO. Perusahaan sama-sama melakukan manajemen laba setelah pergantian CEO. Pada satu tahun setelah pergantian CEO ter perusahaan melakukan manajemen laba dengan pola income decreasing dan setelah dua tahun pergantian CEO ter perusahaan juga melakukan manajemen laba dengan pola income increasing. Penelitian ini sejalan dengan hasil penelitian dari Adiasih dan Kusuma (2011), Choi et al. (2014) dan Wijaya \& Ardiana (2014) mengenai manajemen laba yang dilakukan antara pergantian CEO rutin maupun non-rutin tidak memiliki perbedaan manajemen laba pada peristiwa pergantian CEO. Penelitian ini membuktikan bahwa manajemen laba sudah banyak terjadi dan dilakukan oleh manajer perusahaan go public demi memperoleh keuntungan pribadi dan diharapkan berefek pada minat investor untuk berinvestasi di perusahaannya.

\section{SIMPULAN}

Berdasarkan hasil analisis dan pembahasan yang telah dilakukan sebelumnya, selama dua tahun setelah pergantian CEO dengan menggunakan variabel DA dan PER tanpa melibatkan pengumuman lainnya menunjukkan adanya manajemen laba setelah satu dan dua tahun pergantian CEO. Maka kesimpulannya sebagai berikut 1) hasil uji regresi linier sederhana menghasilkan bahwa selama dua tahun setelah pergantian CEO manajemen laba tidak berpengaruh pada reaksi pasar dengan nilai signifikansi 0,338 dan 0,331>0,05. Berarti bahwa pengumuman pergantian CEO tidak memiliki kandungan informasi bagi seluruh sektor yang termasuk indeks LQ45; 2) berdasarakan hasil uji paired sample t-test manajemen laba pada satu dan dua tahun setelah pergantian CEO tidak terdapat perbedaan yang berarti pada kedua tahun ter adanya praktik manajemen laba. Hasil paired sample t-test selanjutnya adalah reaksi pasar pada satu dan dua tahun setelah pergantian CEO tidak terdapat perbedaan yang berarti kedua tahun ter tidak ada reaksi pasar yang dipengaruhi oleh manajemen laba.

\section{REFERENSI}


Adiasih, P., \& Kusuma, I. W. (2011). Manajemen Laba Pada Saat Pergantian CEO (Dirut) Di Indonesia. Jurnal Akuntansi dan Keuangan, 13 (2), 67-79.

Ardiati Aloysia Yanti. 2005. Pengaruh Manajemen Laba Terhadap Return Saham pada Perusahaan yang Diaudit oleh KAP Big 5 dan KAP Non Big 5. Jurnal Riset Akuntansi Indonesia. Vol. 8 No. 3, Hal. 235-249.

Astika, I. B. Putra. (2009). Hubungan Keagenan dan Hukum Besi Dalam Manajemen Laba. Jurnal Ilmiah Akuntansi dan Bisnis, 4(2). 200-213

Bengtsson, Kristian, Class Bergstrom, dan Max Nilsson. (2006). Earnings Management and CEO Turnovers. Working Paper, School of Aconomics, Sweden.

Brigham, E. F., dan Houston, J. F. (2008). Dasar-Dasar Manajemen Keuangan. Diterjemahkan oleh Ali Akbar Yulianto, Buku 2, Edisi II. Jakarta: Salemba Empat.

Bursa Efek Indonesia. (2019). http://www.idx.co.id/perusahaan-tercatat/profilperusahaan-tercatat. Diakses 15 Desember 2019.

Choi, J. S., Kwak, Y. M., \& Choe, C. (2014). Earnings Management Surrounding CEO Turnover: Evidence from Korea. ABACUS, 50(1), 25-55.

Clayton, M. J., Hartzell, J.C., dan Rosenberg, J. (2003). The Impact CEO Turnover on Firm Volatility. http://www.ssrn.com

Dechow, P., Hutton, A., Kim, j. H., dan Sloan, R. G. (1995). Detecting Earnings Management. The Accounting Review, 70(2), pp. 193-225

Dhinata, I. P. S., \& Wirama, D. G. (2015). Manajemen Laba Pada Event Pergantian Chief Executive Officer di Perusahaan yang Terdaftar di Bursa Efek Indonesia. E-Jurnal Akuntansi Universitas Udayana. 10(2), 326-339.

Eisenhardt, K. M. (1989). Agency Theory: An Assessment an Review. The Academy of Management Review, Vol.14, No.1 (Jan., 1989), pp. 57-74.

Erawan, I. G. P., \& Ulupui, I. G. K. A. (2013). Manajemen Laba Sebelum dan Sesudah Pergantian Chief Executive Officer (CEO). E-Jurnal Akuntansi Universitas Udayana, 3(1), 55-72.

Febriani, D. (2014). Pengaruh Manajemen Laba terhadap Nilai Perusahaan dengan Mekanisme Corporate Governance sebagai Variabel Pemoderasi. Skripsi. Universitas Lampung.

Feng Yu-Chia. 2012. CEO Turnover, Earnings Management, and Big Bath.

Ferro, D., Haryetti, \& Wijaya, E. Y. (2014). The Influence Earning Management on Firm Value by Good Corporate Governance Indeks as Moderating Variable. JOM FEKOM, 1(2), 1-17.

Fundenberg, Drew and Jean Tirole. (1995). "A Theory of Income and Devidend Smoothing Based on Incumbency Rates". Journal of Political Economy. February. 75-93.

Gill, A., Biger, N., Mand, H. S., \& Mathur, N. (2013). Earning Management, Firm Performance, and The Value of Indian Manufacturing Firms. International Research Journal of Finance and Economics, (116), pp 120-132.

Hassen, R. M. (2014). Executive Compensation and Earning Management. International Journal of Accounting and Financial Reporting, 4(1): 84-105

Jayanthi, P. Y. and Putra, I. W. (2013) 'Manajemen Laba dan Respon Pasar Di Sekitar Pergantian CEO', 1, pp. 147-162.

Jensen, M.C dan Meckling, W.H. (1976). Theory of the Firm : Managerial 
Behavior, Agency Cost, Ownership Structure. Journal of Financial Economics, 3, hal. 1-78.

Jin, Lianhua., Jung-Hwa, Lee \& Zhi Hua, Zhang. 2010. CEO Behaviour Regarding Pre-Turnover Earnings Management.

Jogiyanto, H.M. (2017). Teori Portofolio dan Analisis Investasi, Edisi Kesebelas. Yogyakarta: BPFE

Larastomo, J. et al. (2016) 'Pengaruh Tata Kelola Perusahaan dan Penghindaran Pajak Terhadap Manajemen Laba Pada Perusahaan Manufaktur di Indonesia', Esensi, 6(1), pp. 63-74. doi: 10.15408/ess.v6i1.3121.

Noor, I. K., \& Astika, I. B. (2016). Perbedaan Kinerjs dan Nilai Perusahaan Sebelum dan Setelah Pergantian Chief Executive Officer. E-Jurnal Akuntansi Universitas Udayana, 17(2), pp 1057-1082.

Novitasari, P. M., Suranta, S. and Setiawan, D. (2016) 'PERGANTIAN CHIEF EXECUTIVE OFFICER (CEO) DAN KINERJA AKUNTANSI (Studi Empiris pada Perusahaan Non-Keuangan yang Listing di BEI Tahun 2001-2012)', Jurnal Akuntansi, 3(2), pp. 1-15. doi: 10.24964/ja.v3i2.47.

Putri, N. and Fadhlia, W. (2017) 'Pergantian Ceo, Penghindaran Pajak, Kompensasi Eksekutif dan Manajemen Laba Studi Kausalitas pada Perusahaan Manufaktur Indonesia', Jurnal Ilmiah Mahasiswa Ekonomi Akuntansi (JIMEKA), 2(3), p. 1.

Ramantha, Wayan dan Kartika Putri (2014) 'pengaruh pergantian ceo profitabilitas', 26, pp. 2011-2012.

Ridwan, M., \& Gunardi, A. (2013). Peran Mekanisme Corporate Governance sebagai Pemoderasi Praktik Earning Management Terhadap Nilai Perusahaan. Trikonomika, 12(1), pp 49-60.

Sadia, N. and Sukartha, I. (2014) 'Pengaruh Pergantian Ceo Pada Praktik Manajemen Laba Perusahaan Publik Yang Terdaftar Di Bursa Efek Indonesia', E-Jurnal Akuntansi, 8(1), pp. 200-210.

Scott, W., R. (2015). Financial Accounting. Seventh Edition. Pearson: Toronto.

Setiawan, Doddy, Santoso Tri Hananto dan Phua Lian Kee. (2011). An Analysis Of Market Reaction Executive Turnover Announcement In Indonesia : A Trading Volume Approach. Journal of Business and Economic Research. Vol.9 No.11.

Subramanyam, K. R., Wild, J. J. 2013. Analisis laporan keuangan. Buku 1 edisi 10. Jakarta: Salemba Empat.

Suffian, M. T. M., Sanusi, Z. M., \& Mastuki, N. A. (2015). Real Earnings Management and Firm Value. Malaysian Accounting Review, 14(1), pp 26-47.

Sugiyono. (2018). Metode Penelitian Bisnis. Bandung: C.V. Alfabeta.

Susanto, S., \& Christiawan, Y. J. (2016). Pengaruh Earning Management Terhadap Firm Value. Business Accounting Review, 4(1), 205-216.

Swasti, Ni Wayan Mahoni, Majidah dan Triyanto, Dodik, N. (2016) ' Praktik Manajemen Laba dan Reaksi Pasar Pada Event Pergantian CEO Di Perusahaan Go Public Non Keuangan Yang Terdaftar Di BEI Tahun 20102014'.

Warner, J. B., Watts, R. L., and Wruck, K. H. (1988). Stock Prices and Top Management Changes. Journal of Financial Economics, 20, pp 461-492

Wells, P. (2002). Earnings Management Surrounding CEO Changes Accounting 
and Finances, 42: 169-193.

Widyaningdyah, A.U. (2001). Analisis Faktor-Faktor Yang Berpengaruh Terhadap Earning Management Pada Perusahaan Go Public di Indonesia. Jurnal Akuntansi dan Keuangan. 3(2), hlm. 89-101.

Wijaya, B. A. and Ardiana, P. A. (2014) 'Manajamen Laba Pada Peristiwa Pergantian Chief Executive Officer', E-Jurnal Akuntansi Universitas Udayana, 2, pp. 263-278.

Yasa, G. W., \& Novialy, Y. (2008). Manajemen Laba oleh Chief Executive Officer (CEO) Baru pada Perusahaan-perusahaan yang Terdaftar di Pasar Modal Indonesia. Jurnal Ilmiah Akuntansi Dan Bisnis Universitas Udayana, 7(1), pp 124. 